\title{
EFFECTS OF MO AND Cr ON MICROSTRUCTURES AND MECHANICAL PROPERTIES OF HOT ROLLED C-MN-V ADVANCED HIGH STRENGTH STEELS*
}

\author{
Charles de Abreu Martins ${ }^{1}$ \\ Nina M. Fonstein ${ }^{2}$ \\ Leonardo Barbosa Godefroid ${ }^{3}$
}

\begin{abstract}
An experimental investigation was conducted using laboratory-processed, $0.12 \mathrm{C}-$ $1.70 \mathrm{Mn}-0.2 \mathrm{~V}$ steels with different $\mathrm{Cr}$ or Mo additions aiming to evaluate this influence on the microstructure and mechanical properties hot rolled steels. Steels were processed in a pilot rolling equipment, simulating a typical thermomechanical processing, with finishing rolling steps above $\mathrm{Ar}_{3}$, followed by accelerated cooling and $723 \mathrm{~K}$ (450 Celsius) coiling temperature. Microstructures and precipitates were analyzed using OM, SEM and TEM, while mechanical properties were evaluated by tensile and hole expansion tests. Since $\mathrm{Cr}$ and Mo increase hardenability of austenite, and as a consequence, the volume fraction of the acicular constituents increases with gradual additions of $\mathrm{Cr}$ or Mo. Moreover, $\mathrm{Cr}$ or Mo impacted $\mathrm{V}$ precipitation process, reducing average size of particles. At $0.50 \% \mathrm{Mo}$, $\mathrm{V}$ precipitation was inhibited. Effects of this microstructure evolution on the final mechanical properties were also analyzed, as well as a comparison between $\mathrm{Cr}$ and Mo effects, with Mo presenting more effective influence.
\end{abstract}

Keywords: Microstructures; Precipitation; Thermomechanical processing; Effect of Cr and Mo; C-Mn-V Steel.

1 Engenheiro Metalúrgico, Doutor, Gerente de Metalurgia, ArcelorMittal Tubarão, Vitória-ES, Brasil.

2 Engenheira Metalúrgica, Doutora, Scientific Advisor, ArcelorMittal Global R\&D, Chicago-IN, Estados Unidos.

3 Engenheiro Metalúrgico, Doutor, Professor, REDEMAT/UFOP, Ouro Preto-MG, Brasil.

* Contribuição técnica ao $51^{\circ}$ Seminário de Laminação - Processos e Produtos Laminados e Revestidos, 28 a 31 de outubro de 2014, Foz do Iguaçu, PR, Brasil. 


\section{INTRODUCTION}

Nowadays in automotive industry, strong demands for smaller fuel consumption and safety regulation imposed conflicting requirements on auto bodies: they are required to be both lighter and more mechanically resistant. Expanded application of high strength steel sheets is extremely important for reducing auto body weight and securing crashworthiness.

The efficiency of combined use of several hardening mechanisms obtained by multiple addition of alloying elements, associated with thermomechanical processing like controlled rolling and accelerated cooling, have allowed the development of advanced high strength steels (AHSS).

Among AHSS, steels with controlled microstructure formed by an adequate combination of microconstituents, have led to increasing level of mechanical resistance, keeping competitive values of ductility and formability, being called multiphase or complex phase steels [1-16].

Additions of $\mathrm{Cr}$ or Mo has been used in multiphase steels and there are publications showing that these elements increase hardenability, mainly due to solute drag effect, supporting hardening by acicular microstructure like bainite and martensite [5,17-20]. Moreover, it has been showed [1-5] that there is an effective influence of Mo or Cr on the microalloying elements precipitation, mainly increasing the precipitates stability, controlling their sizes in isothermal treatments or in continuous cooling processes.

Concerning to the impact of $\mathrm{Cr}$ or Mo addition on hole expansion performance, it is defined by the influence of these elements on the microsctrucure. Although it is not completely clarified, there are publications [21,22] showing that the presence of bainite in multiphase steels may increase the hole expansion.

Although there are several papers exploring isolated effects of Mo and $\mathrm{Cr}$, as well as the combined action of Mo or $\mathrm{Cr}$ with $\mathrm{Nb}$, Ti or B [1-5,15,23-26], it is not well explored the effect of Mo or $\mathrm{Cr}$ with $\mathrm{V}$ in hot rolled multiphase steels.

Then, this work aimed to evaluate the influence of $\mathrm{Cr}$ or Mo additions on the microstructure and mechanical properties of hot rolled AHSS, including hole expansion test, with a chemical composition based on $\mathrm{C}-\mathrm{Mn}-\mathrm{V}$.

\section{EXPERIMENTAL PROCEDURE}

Five laboratory heats alloyed with different amounts of $\mathrm{Cr}$ or Mo were investigated. Elements such as sulfur, phosphorus, copper, and nickel are present only in residual levels. The chemical compositions of the studied steels are shown in Table 1. Heats of $45 \mathrm{~kg}$ of the steels were melted in a vacuum induction furnace. Thermomechanical processing was conducted in laboratory in two steps. The ingots, reheated at $1493 \mathrm{~K}$ (1220 Celsius), were hot-rolled into plates of $20 \mathrm{~mm}$ thick. Plates were reheated again at $1493 \mathrm{~K}$ (1220 Celsius) and processed into hot-rolled sheets of $4.0 \mathrm{~mm}$ gauge with finishing rolling temperature of $1123 \mathrm{~K}$ (850 Celsius), followed by water cooling on the laboratory run out table, with water sprays from both sides. In this laboratorial procedure, in order to simulate the coiling process, hot rolled sheets cooled to $723 \mathrm{~K}$ (450 Celsius) were transferred to a furnace, held for $1 \mathrm{~h}$ at $723 \mathrm{~K}$ (450 Celsius), and cooled to room temperature within the furnace.

Dilatometry was conducted using a MMC quenching dilatometer with inductive furnace for heating and nitrogen or helium injection for cooling. The samples used were $10 \mathrm{~mm}$ long solid cylinders with a diameter of $5 \mathrm{~mm}$. Temperature control was done by a $0.1 \mathrm{~mm}$ thermocouple welded on the sample surface.

\footnotetext{
* Contribuição técnica ao $51^{\circ}$ Seminário de Laminação - Processos e Produtos Laminados e Revestidos, 28 a 31 de outubro de 2014, Foz do Iguaçu, PR, Brasil.
} 


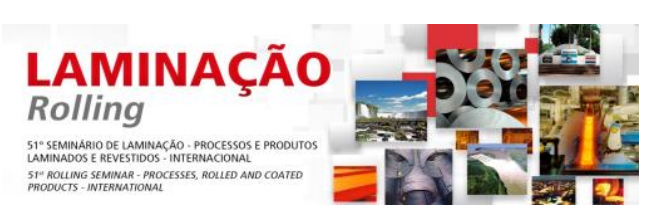

Table 1_Chemical composition of the investigated steels, wt.\%

\begin{tabular}{cccccc} 
Steel & $\mathrm{C}$ & $\mathrm{Mn}$ & $\mathrm{V}$ & $\mathrm{Cr}$ & $\mathrm{Mo}$ \\
\hline Base & 0.12 & 1.69 & 0.20 & - & - \\
$0.25 \mathrm{Cr}$ & 0.12 & 1.69 & 0.19 & 0.25 & - \\
$0.50 \mathrm{Cr}$ & 0.12 & 1.70 & 0.21 & 0.50 & - \\
$0.25 \mathrm{Mo}$ & 0.12 & 1.70 & 0.20 & - & 0.25 \\
$0.50 \mathrm{Mo}$ & 0.12 & 1.69 & 0.20 & - & 0.50 \\
\hline
\end{tabular}

Investigation of microstructures and phase quantification were conducted using both light microscopy and scanning electron microscopy. Samples were etched with $2 \%$ Nital. Volume fractions of carbon-containing phases such as bainite and martensite were calculated manually using a grid containing 910 small squares. Three fields were analyzed for each sample.

Precipitates identification was conducted using transmission electron microscopy with EDS, as well as an image analyzer Clemex Vision Professional, model 6.0. Carbon Replica technique was used to prepare samples.

Tensile tests of hot rolled samples, cut in the L-direction, were performed at room temperature, in accordance with ASTM A 370. Ultimate tensile strength (UTS), yield strength (YS), and total elongation (TE) were evaluated using an initial length of $25 \mathrm{~mm}$ and test speed of $0,5 \mathrm{~cm} / \mathrm{min}$.

Hole expansion tests following ISO 16630 were conducted on a MTS 866 Hole Expansion Tester with a 66 ton Press Machine for hole punching, produced by Seyi manufacturer. This hole had $10 \mathrm{~mm}( \pm 0.01 \mathrm{~mm})$ and it was done in the centre of each $90 \mathrm{~mm}$ squares sample. A camera connected to a computer with a semi-automatic software was used to identify the image of the first-through-thickness crack from image records and to calculate the hole expansion ratio based on the image being identified. Hole expansion value in percentage, $\lambda(\%)$, was calculated using the following equation:

$$
\lambda(\%)=\frac{\left(D_{f}-D_{0}\right) x 100}{D_{0}}
$$

Where $D_{0}$ is the initial hole diameter and and $D_{f}$ is the hole diameter when the firstthrough-thickness crack appeared.

\section{RESULTS E DISCUSSIONS}

\subsection{Effect of Cr and Mo on Hardenability}

Cr or Mo additions impacted effectively hardenability, reducing $\mathrm{Ar}_{3}$ value and affected on volume fraction of microconstituents obtained after laboratory thermomechanical processing.

$\mathrm{The}_{3}$ values were identified from the dilatometry procedures and are showed in Table 2.

\footnotetext{
* Contribuição técnica ao $51^{\circ}$ Seminário de Laminação - Processos e Produtos Laminados e Revestidos, 28 a 31 de outubro de 2014, Foz do Iguaçu, PR, Brasil.
} 


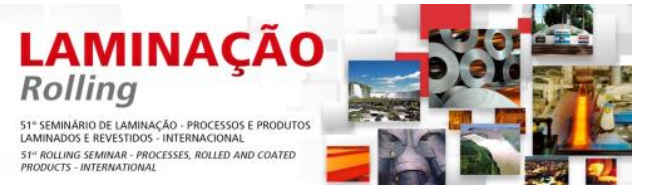

Figure 2 shows the volume fraction evolutions of microconstituents for different additions of $\mathrm{Cr}$ or Mo. This Fig. shows that both $\mathrm{Cr}$ and Mo increased C-Mn-V steel hardenability, increasing martensite volume fractions and reducing ferrite and bainite volume fractions.
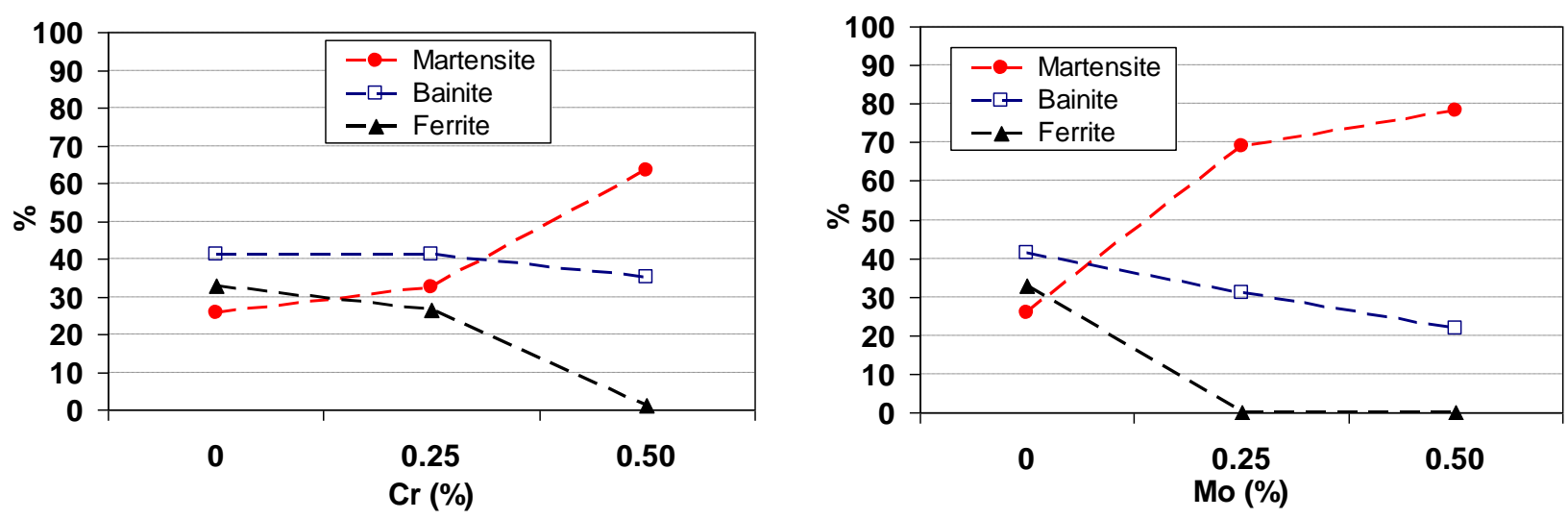

Figure 2 - Effect of $\mathrm{Cr}$ or Mo additions on microconstituents volume fractions.

As can be seen the $0.25 \% \mathrm{Cr}$ does not change the volume fraction of martensite in comparison with basic $\mathrm{C}-\mathrm{Mn}-\mathrm{V}$ steel. The other compositions showed a significant increase in \% of martensite, around 65 to $80 \%$, with reduction of ferrite and bainite presences.

The effects of $\mathrm{Cr}$ or Mo addition on $\mathrm{Ar}_{3}$ value and \%microconstituents can be explained by the increasing hardenability by $\mathrm{Cr}$ or Mo in solid solution which retards the austenite decomposition due to solute drag effect [5-8, 17-19]. Mo is more effective in this process since its atomic diameter is $22 \%$ higher than iron and $\mathrm{Cr}$ is only $6.5 \%$ higher. There are publications citing that Mo can be up to 3 times more effective than $\mathrm{Cr}$ to increase hardenability [17, 19].

Absence of pearlite in all steels can be explained also by increased hardenability, even in base $\mathrm{C}-\mathrm{Mn}-\mathrm{V}$ steel. The applied thermomechanical processing, including accelerated cooling and low coiling temperature was also effective to avoid pearlite transformation in this steel.

\subsection{Cr or Mo Effects on Precipitation}

Precipitation analysis in the C-Mn-V base steel identified $\mathrm{V}$ precipitates with average size of $21.7 \mathrm{~nm}$, Fig. 3. These precipitates have a circular morphology and are homogeneously distributed in the matrix. It was not identified aligned precipitates typical from austenite to ferrite transformation.

TEM analysis in the $0.50 \% \mathrm{Cr}$ steel identified smaller precipitates of $\mathrm{V}$, with average size of $14.9 \mathrm{~nm}$, Fig. 4. It was identified qualitatively a smaller volume fraction of precipitates when this steel compared with the C-Mn-V steel.

TEM analysis in the $0.50 \%$ Mo steel did not identified precipitates. It can be concluded that all $\mathrm{V}$ is in solid solution due to higher solubility in the presence of $0.50 \% \mathrm{Mo}$.

These results from TEM analysis is in agreement with shown effect of $\mathrm{Cr}$ or Mo reducing activity of $\mathrm{C}$ and $\mathrm{N}$ in austenite, increasing the solubility of microalloying elements, as well as retarding the precipitation process and increasing the presence

* Contribuição técnica ao $51^{\circ}$ Seminário de Laminação - Processos e Produtos Laminados e Revestidos, 28 a 31 de outubro de 2014, Foz do Iguaçu, PR, Brasil. 


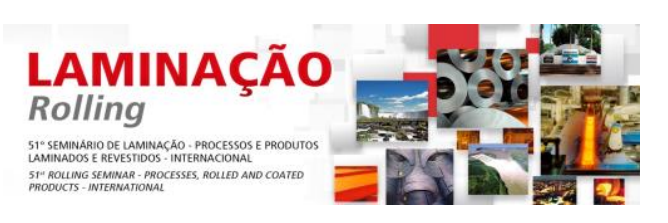

Accelerated cooling after rolling steps used in this work as well as low coiling temperature, $723 \mathrm{~K}$ (450 Celsius), also contributed to inhibit V precipitation process, because there was no enough time for the diffusion process.

The combined action of $\mathrm{Cr}$ or Mo additions with accelerated cooling and low coiling temperature had an effective impact on precipitation process, reducing amount and size of precipitates when $0.50 \% \mathrm{Cr}$ was added and eliminating precipitation process when $0.50 \%$ Mo was added. Figure 5 shows the stronger effect of Mo compared with Cr.

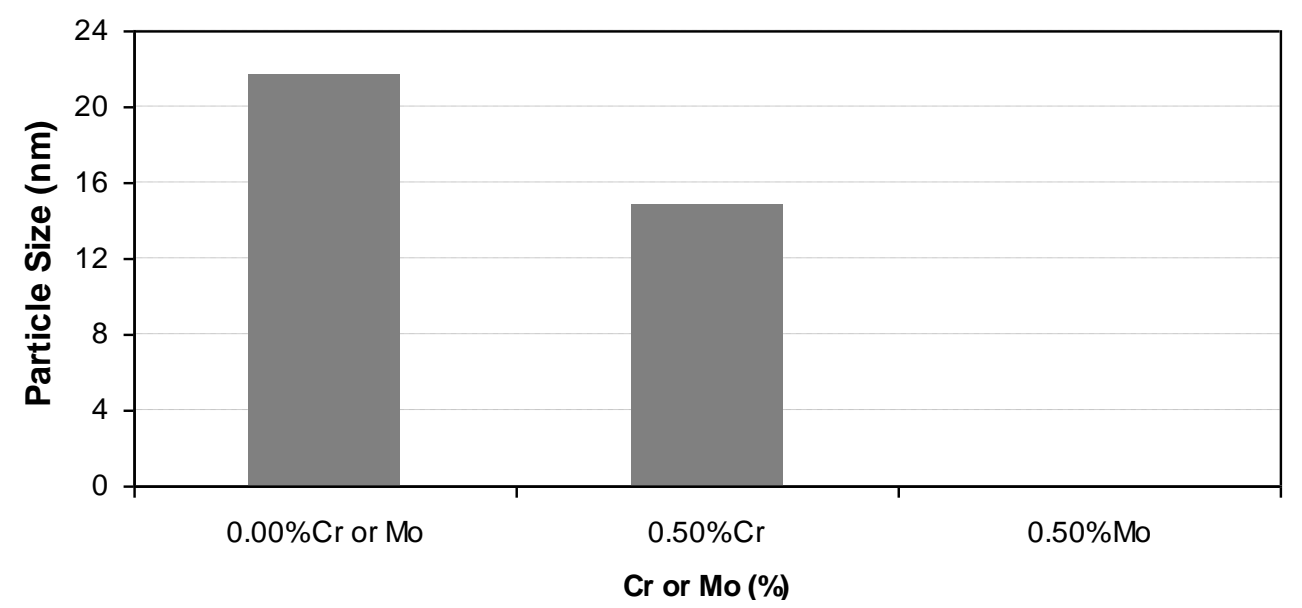

Figure 5 - Evolution of $\mathrm{V}$ precipitates average size with $\mathrm{Cr}$ or Mo addition.

In this way, additions of $\mathrm{Cr}$ or Mo at applied themomechanical processing with coiling temperature of $723 \mathrm{~K}$ (450 Celsius), allowed a more intense effect of these elements in hardenability, but limited the contribution of $\mathrm{V}$ to precipitation hardening process.

A higher coiling temperature might allow a combined action of both effect, high hardenability from $\mathrm{Cr}$ or Mo presence and more effective precipitation hardening by $\mathrm{V}$ particles due to easier diffusion process.

\subsection{Cr or Mo Effects on Mechanical Properties}

Tensile mechanical properties are presented in Figures. 6 and 7 as a function of $\mathrm{Cr}$ or Mo content in the steels studied. Using relationships shown in Fig. 2 between the content $\mathrm{Cr}$ and $\mathrm{Mo}$ and the volume fraction of martensite, it was generated the graphic of Figure 8, which shows the effect of martensite on mechanical strength of the materials. It can be concluded that Mo has a stronger effect on strengthen of steel than the $\mathrm{Cr}$, but at accordingly reducing elongation. This impact was mainly because of the increase of martensite volume fraction, caused by effect of $\mathrm{Cr}$ or Mo increasing on hardenability, as was explained previously.

Although tensile mechanical properties varied with $\mathrm{Cr}$ or Mo addition, all specimens presented a ductile fracture with cup and cone characteristic, started from voids nucleated at heterogeneous sites such as inclusions, as can be seen in Figure 9.

With respect to the hole expansion tests, it was identified a relationship between the bainite content and the hole expansion ratio, as shown in Figure 10. The presence of bainite may reduce the difference in hardness between the ferrite and strengthening martensite phases, increasing the steel performance during this test. This relationship was already identified in previous publications. [21, 22].

* Contribuição técnica ao $51^{\circ}$ Seminário de Laminação - Processos e Produtos Laminados e Revestidos, 28 a 31 de outubro de 2014, Foz do Iguaçu, PR, Brasil. 


\section{LAMINAÇÃO \\ Rolling}
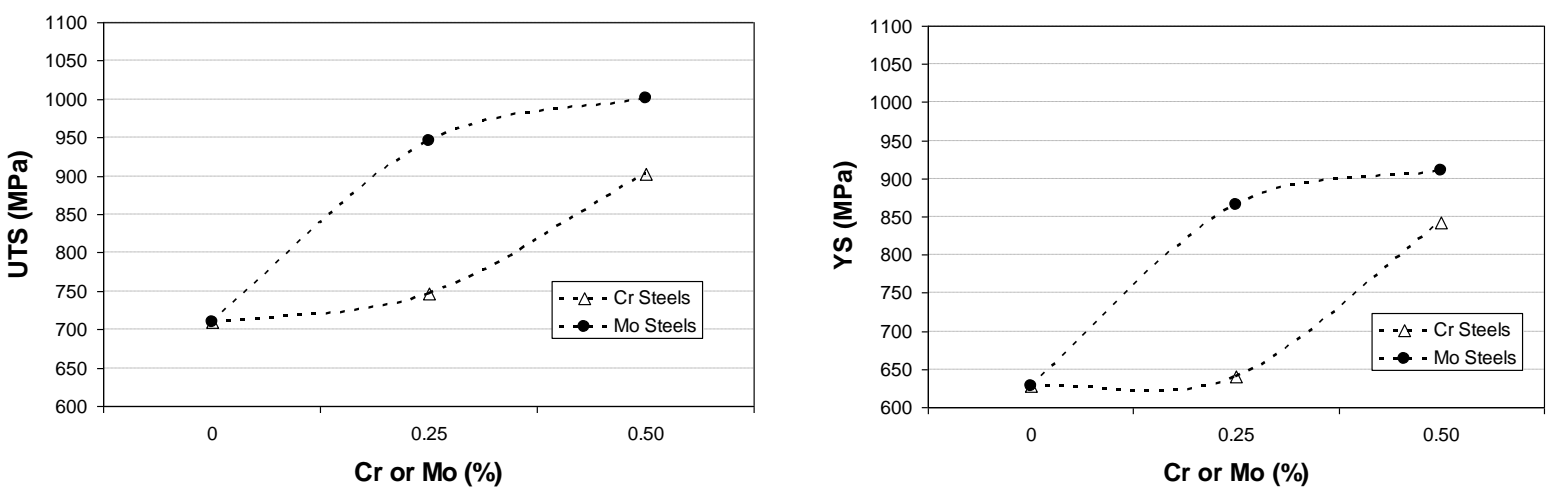

Figure 6 - Effect of $\mathrm{Cr}$ or Mo addition on YS and UTS values.

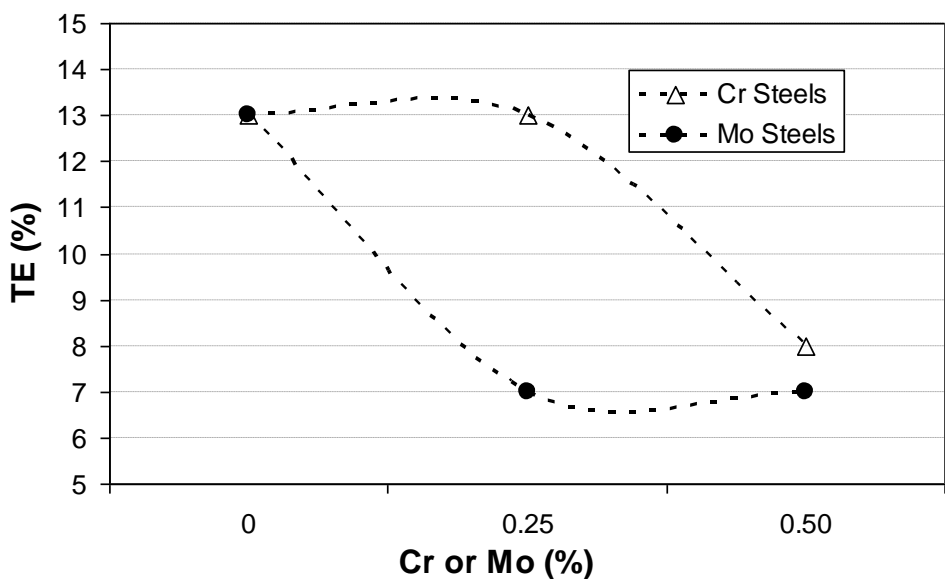

Figure 7 - Effects of $\mathrm{Cr}$ or Mo on TE value.

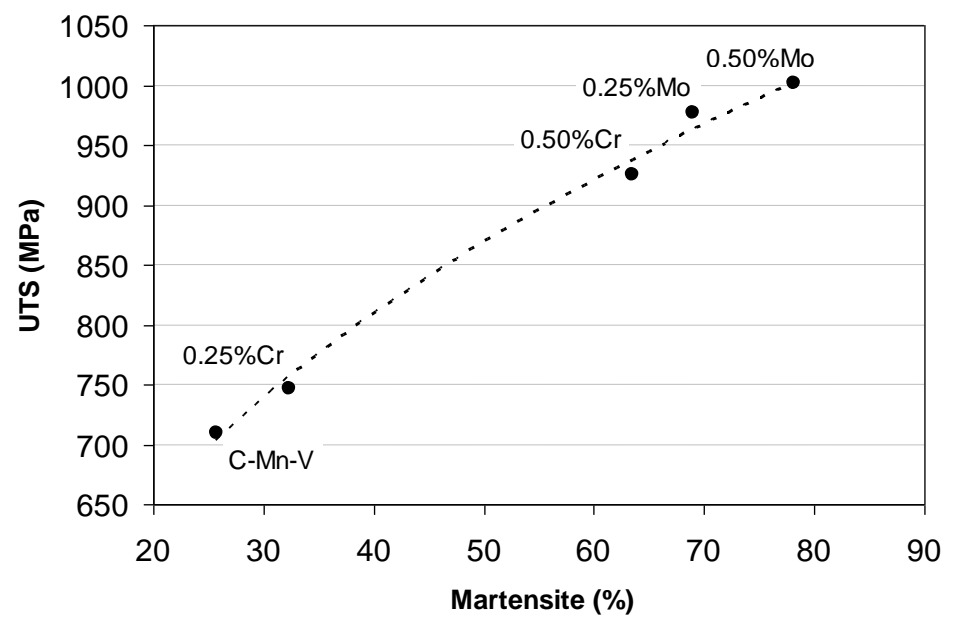

Figure 8 - Effect of martensite volume fraction on UTS taking into account all steels studied.

* Contribuição técnica ao $51^{\circ}$ Seminário de Laminação - Processos e Produtos Laminados e Revestidos, 28 a 31 de outubro de 2014, Foz do Iguaçu, PR, Brasil. 

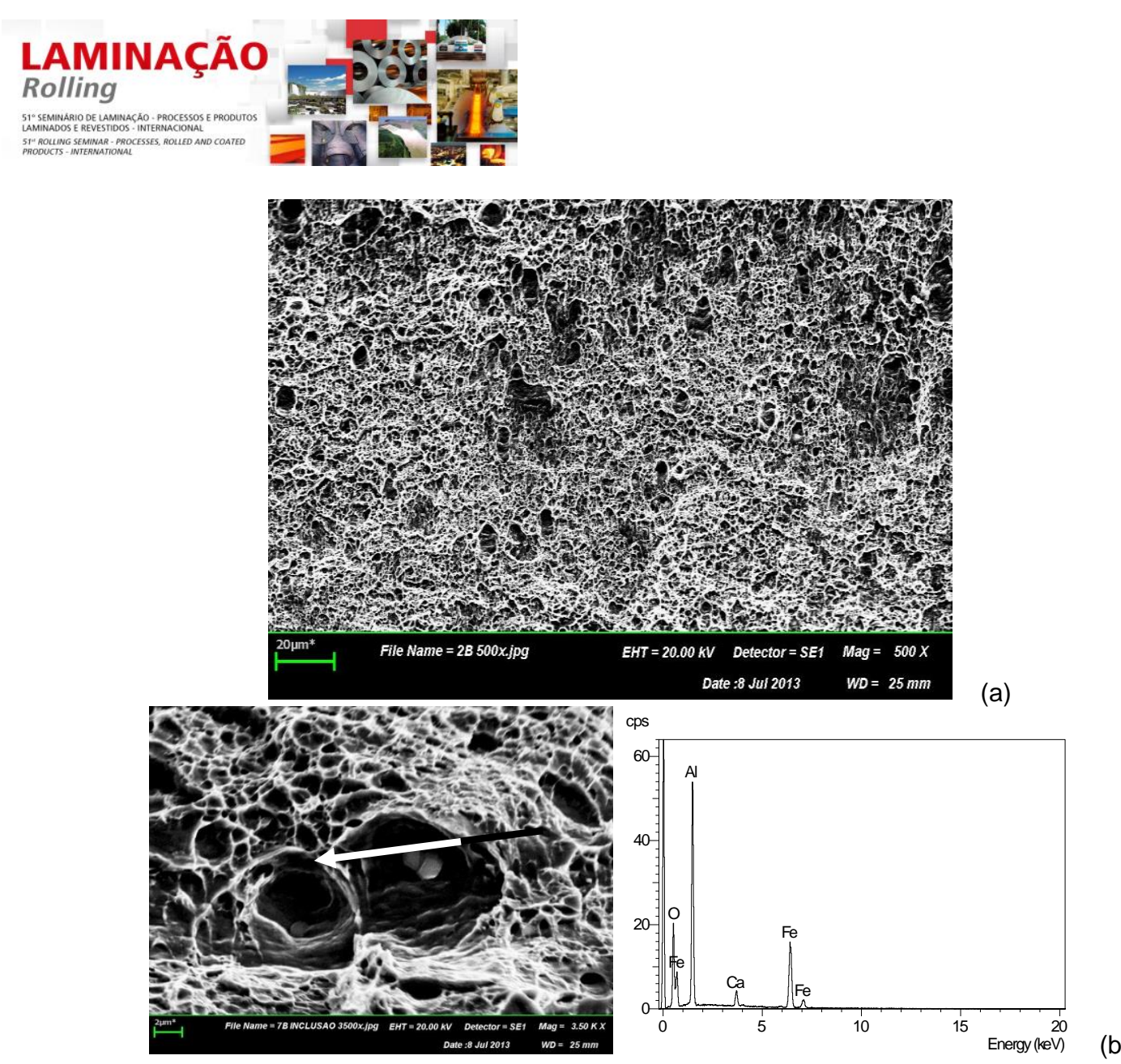

Figure 9 - (a) Ductile fracture surface observed in all tensile specimens. (b) Fracture surface in detail, showing a calcium aluminate inclusion (characterization by SEM and EDS).

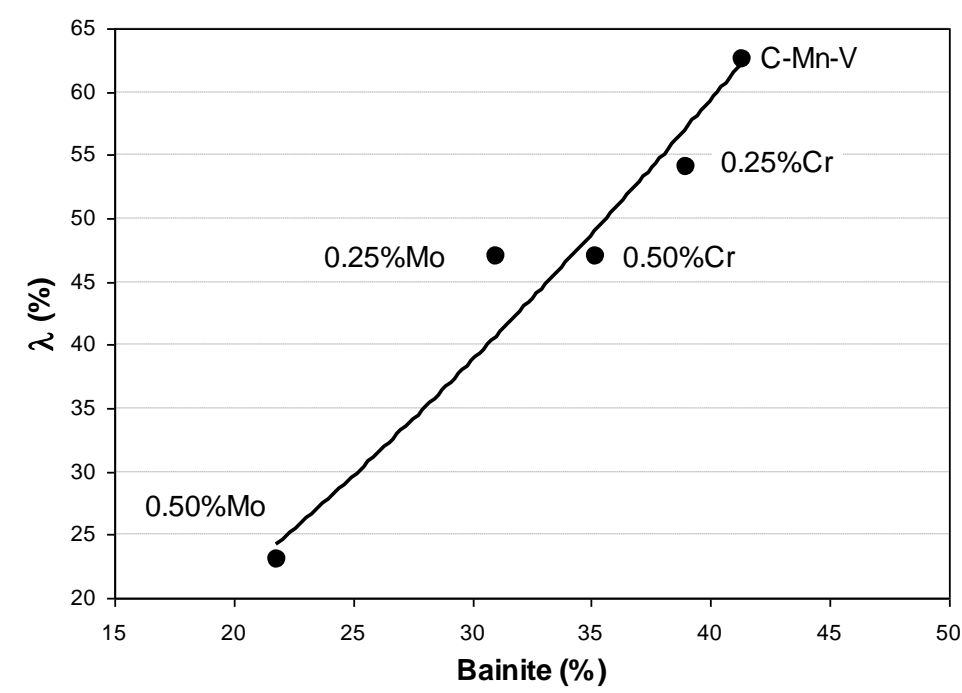

Figure 10 - Effect of bainite volume fraction on hole expansion ratio $(\lambda(\%))$.

\section{CONCLUSIONS}

1. The study of basic C-Mn-V steel using a thermomechanical processing with low coiling temperature, $723 \mathrm{~K}$ (450 Celsius), has shown that both $\mathrm{Cr}$ and Mo additions decreased $\mathrm{Ar}_{3}$ temperature, suppressed ferrite formation and increased amount of martensite, because of increasing hardenability. Mo was more effective: the addition of $0.25 \%$ Mo resulted in increase in hardenability as $0.50 \% \mathrm{Cr}$;

* Contribuição técnica ao $51^{\circ}$ Seminário de Laminação - Processos e Produtos Laminados e Revestidos, 28 a 31 de outubro de 2014, Foz do Iguaçu, PR, Brasil. 


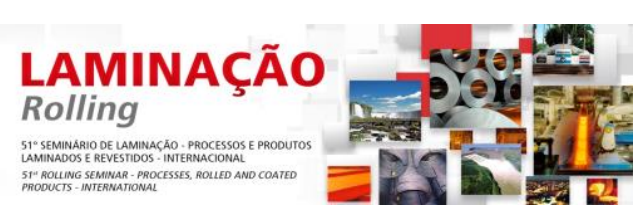

2. This increasing of martensite volume fraction increased UTS and YS, reducing TE with a good correlation, allowing to identify an almost linear relationship between UTS and \%martensite;

3. Hole expansion ratio demonstrated a good relationship with volume fraction of bainite, because of reduction of difference of strength between ferrite and bainite in comparison with martensite in steels studied;

4. It was identified that $\mathrm{Cr}$ and Mo affected the $\mathrm{V}$ precipitation process, reducing its kinetics. As a consequence, increasing the $\mathrm{Cr}$ or Mo additions reduced the average size of the precipitates and, qualitatively, it was possible to detect a reduction of the total amount of precipitates. . At $0.50 \% \mathrm{Mo}, \mathrm{V}$ precipitation was inhibited.

\section{Acknowledgments}

The authors thank ArcelorMittal for the permission to publish this article and Astrid Perlade of ArcelorMittal Global R\&D, Maizières, France, for her critical input to the design of experiments.

\section{REFERÊNCIAS}

1 Tamura I, Ouchi C, Tanaka T, Sekine H. Thermomechanical Processing of HighStrength Low-Alloy Steels, p. 248, Butterworths and Co., London, 1988.

2 Martins CA, Poliak E, Godefroid LB, Fonstein N. Determining the Conditions for Dynamic Recrystallization in Hot Deformation of C-Mn-V Steels and the Effects of $\mathrm{Cr}$ and Mo Additions. ISIJ International, 2014; 54(1): 227-234.

3 Martins CA, Godefroid LB, Fonstein N, Boratto FJM. Efeitos de Temperatura de Austenitização, Taxa de Resfriamento e Elementos de Liga nas Transformações de Fases de um Aço C-Mn-V. 69 ABM International Annual Congress, São Paulo, Brazil, 2014

4 Cuddy LJ. Microstructures Developed During Thermomechanical Treatment of HSLA Steels. Metallurgical Transactions A, 1981; 12 A: 1313-1320.

5 Pickering FB. The Spectrum of Microalloyed High Strength Low Alloy Steels. In: HSLA Steels: Metallurgy and Applications, 1985, Beijing, China. Proceedings of International Conference on HSLA Steels' 85... ASM International, 1986. p. 1-31.

6 Meyer L, Strabburger C, Schneider C. Effect and Present Application of the Microalloying Elements Nb, V, Ti, Zr and B in HSLA Steels. In: HSLA Steels: Metallurgy and Applications, 1985, Beijing, China. Proceedings of International Conference on HSLA Steels' 85... ASM International, 1986. p. 29-39.

7 Asahi $\mathrm{H}$. Effects of Mo Addition and Austenitizing Temperature on Hardenability of Low Alloy B-Added Steels. ISIJ International, 2002; 42(10): 1150-1155.

8 Woodhead JH. The Physical Metallurgy of Vanadium Steels. In: VANITEC International Symposium, 2000, Guilin, China. Anais... 2000. p. 3-10.

9 Murakami T, Hatano H, Miyamoto G, Furuhara T. Effects of Ferrite Growth Rate on Interphase Boundary Precipitation in V Microalloyed Steels. ISIJ International, 2012; 52 (4): 616-625.

10 Hasegawa K, Kawamura K, Urabe T, Hosoya Y. Effects of Microstructure on Stretchflange-formability of $980 \mathrm{MPa}$ Grade Cold-rolled Ultra High Strength Steel Sheets. ISIJ International, 2004; 44(3): 603-609.

11 Quelennec X, Bozzolo N, Jonas JJ, Loge R. A New Approach to Modeling the Flow Curve of Hot Deformed Austenite. ISIJ International, 2011; 51(6): 945-950.

12 Jonas JJ, Quelennec X, Jiang L, Martin ET. The Avrami kinetics of dynamic recrystallization. Acta Materialia, 2009; 57: 2748-2756.

\footnotetext{
* Contribuição técnica ao $51^{\circ}$ Seminário de Laminação - Processos e Produtos Laminados e Revestidos, 28 a 31 de outubro de 2014, Foz do Iguaçu, PR, Brasil.
} 


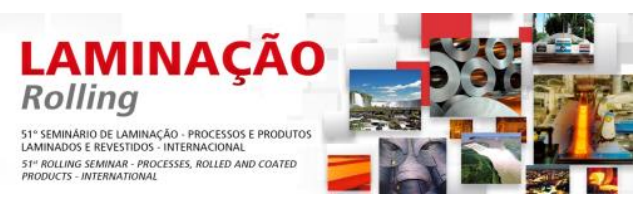

13 Siciliano JrF, Minaml K, Maccagno TM, Jonas JJ. Mathematical Modeling of the Mean Flow Stress, Fractional Softening and Grain Size During of the Hot Strip Rolling of CMn Steel. ISIJ International, 1996; 36(12)1500-1 506.

14 Lenard JG, Tajima M. Thermo-mechanical Treatment of a High Nb-High V Bearing Micro-alloyed Steel. ISIJ International, 1995; 35(12): 1509-1517.

15 Chatterjee S, Ghosh SK, Bandyopadhyay PS, Mishra S. Phase Transformation and Mechanical Properties of an Ultrahigh Strength Steel. Journal of Iron and Steel Research International, 2011; 18: 192-199.

16 Fonstein N. Effect of Al, C and Mn on Structure and Mechanical Properties of DualPhase and TRIP Steels. In: HSLA Steels: Metallurgy And Applications, 2005, Sanya, China. Proceedings of International Conference on HSLA Steels'05... CSM International, 2005. p. 162-167.

17 Hara T, Asahi H, Uemori R, Tamehiro H. Role of Combined Addition of Niobium and Boron and of Molybdenum and Boron on Hardenability in Low Carbon Steels. ISIJ International, 2004; 44(8): 1431-1440.

18 Takahashi M, Kawano O, Hayashida T. High Strength Hot-rolled Steel Sheets for Automobiles. Nippon Steel Technical Report, 2003; 88: 8-12.

19 Mohrbacher H. Principal Effect of Mo in HSLA Steels and Cross Effects with Microalloying Elements. In: International Seminar on Applications of Mo In Steels, 2010, Beijing, China. Proceedings...China, 2010. p. 75-96.

20 Han F, Hwang B, Suh DW, Wang Z, Lee DL, Kim SJ. Effect of Molybdenum and Chromium on Hardenability of Low-Carbon Boron-Added Steels. Metals and Materials International, 2008; 14(6): 667-672.

21 Dong H, Dangsheng M, Yuping L, Song Z, Yang G, Wang M. Effects and Applications of Mo in Alloy Steels. In: International Seminar on Applications Of Mo In Steels, 2010, Beijing, China. Proceedings...China, 2010. p. 2-13.

22 Shinjun S, Quilong W. The Role and Applications of Molybdenum Element in Low Alloy Steels. In: International Seminar on Applications of Mo In Steels, 2010, Beijing, China. Proceedings...China, 2010. p. 61-74.S. Sriram B, Yan M, Huang M. SAE Int., 2004, SAE Paper 2001-01-3075, p. 16.

23 Shirasawa H, Mimura K, Yokoi T, Shibata Z, Inoue N. Formability of TS590 N/mm² TriPhase Hot Rolled Steel, Kobe Steel Ltda, 6 p, 1995.

24 Salemi A, Golestaneh AH, Moosavi-Khoonsari E. Mechanical Behavior of CrMo4 Steel with Dual-phase Microstructure. Proceedings of the 6th International Conference on High Strength Low Alloy Steels (HSLA Steels'2011), 8 p., 2011.

25 Garcia CI, Suikkanen PP, Hua M, Deardo AJ. Modern Microalloyed Steels. In: The $6^{\text {th }}$ International Conference on High Strength Low Alloy Steels, 2011, Beijing, China. Anais HSLA Steels'2011...China: The Chinese Society for Metals, 2011. p. 1-8.

26 Pereda B, Fernández AI, López B, Rodriguez-lbabe JM. Effect of Mo on Dynamic Recrystallization Behavior of Nb-Mo Microalloyed Steels. ISIJ International, 2007; 47(6): 860-868.

* Contribuição técnica ao $51^{\circ}$ Seminário de Laminação - Processos e Produtos Laminados e Revestidos, 28 a 31 de outubro de 2014, Foz do Iguaçu, PR, Brasil. 